ism for calcium through the same final pathway as oral vitamin D (Wills, 1973). It is not yet clear whether in the one to four months after parathyroidectomy the reduction in "early phase" absorption is necessarily compensated for by an increase in "late phase" absorption as suggested by two of the three restudies conducted at that time. In any case a minority of parathyroidectomized patients fail to go into positive calcium balance postoperatively (Hosking et al., 1972 a).

In general it is evident that serial studies of the pattern of calcium absorption, particularly in relation to early and late absorption, are of considerable value, since significant changes in the handling of calcium by the gut are not necessarily demonstrable by simple measurements of overall absorption.

We wish to thank Miss P. Hulme and Mrs. C. Morgan for their thorough dietary assessments, and the sister and nurses of Haldane ward for their help in conducting the tests. Thanks are also due to
Mrs. G. James, Mr. J. D. Pearson, and Mr. G. P. Gibbs for skilled technical help.

\section{References}

Avioli, L. V., et al. (1965). Fournal of Clinical Investigation, 44, 128.

Birge, S. J., et al. (1969). Fournal of Clinical Investigation, 48, 1705.

Dymling, J. F. (1971). In Radioisotopes in Medical Diagnosis, ed. E. H. Belcher and $H$. Vetter, p. 298. London, Butterworth.

Hart, H., and Spencer, H. (1967). Proceedings of the Society for Experimental Biology and Medicine, 126, 365.

Hosking, D. J., Chamberlain, M. J., and Fremlin, J. H. (1972 a). Clinical Science, 43, 627

Hosking, D. J., et al. (1972 b). British Medical fournal, 1, 19

Kinney, V. R., Tauxe, W. N., and Dearing, W. H. (1965). Fournal of Laboratory and Clinical Medicine, 66, 187.

Love, A. H. G., et al. (1973). Clinical Science, 44, 267.

Ogg, C. S., Pearson, J. D., and Veall, N. (1968). Clinical Science, 34, 327.

Scholer, J. F., and Code, C. F. (1954). Gastroenterology, 27, 565

Szymendera, J., Heaney, R. P., and Saville, P. D. (1972). Fournal of Laboratory and Clinical Medicine, 79, 570.

tory and Clinical Medicine, 79,
Wills, M. R. (1973). Lancet, $1,820$.

Woodhouse, N. J. Y., Doyle, F. H., and Joplin, G. F. (1971). Lancet, 2, 283.

\title{
Acetanilide Oxidation in Phenylbutazone-associated Hypoplastic Anaemia
}

\author{
J. L. CUNNINGHAM， M. J. LEYLAND， I. W. DELAMORE， D. A. PRICE EVANS
}

British Medical fournal, 1974, 3, 313-317

\section{Eummary}

Acetanilide like phenylbutazone is paraoxidized by the liver endoplasmic reticulum as a primary biotransformation step. Both compounds were given at different times to each of 10 healthy volunteer subjects and the plasma disappearances measured. Correlation was shown between plasma clearance values of the two compounds $(r=+0.7067 ; P<0.05)$.

Eight patients with hypoplastic anaemia after phenylbutazone therapy were investigated. Plasma clearance values and half lives of acetanilide were measured in this group of patients and compared with those of a group of $\mathbf{3 0}$ healthy volunteer controls. There was a significant decrease in clearance $(P<0.01)$ and lengthening of half lives $(P<0.001$ in the patients with phenylbutazone-associated hypoplasia. Five patients with idiopathic aplastic anaemia-that is, without history of antecedent phenylbutazone ingestion-were similarly investigated with acetanilide and there was no significant difference between the results in these patients and those in the control group.

It is suggested that relatively poor paraoxidation of phenylbutazone producing high blood concentrations on a given dose may be a factor responsible for the drug-associated hypoplasia even though it does not explain the similar pattern of adverse reactions reported in association with oral administration of the metabolite oxyphenbutazone.

Nuffield Unit of Medical Genetics, Department of Medicine, University of Liverpool, Liverpool L69 $3 B X$

J. L. CUNNINGHAM, M.B., M.R.C.P., Wellcome Research Fellow

D. A. PRICE EVANS, M.D., F.R.C.P., Professor

University Department of Clinical Haematology, Manchester Royal Infirmary, Manchester M13 9WL

M. J. LEYLAND, M.R.C.P., Lecturer

I. W. DELAMORE, M.B., F.R.C.P., Consultant Physician

\section{Introduction}

A wide interindividual variation in the ability to oxidize, and therefore to eliminate from the body, phenylbutazone has been shown in man (Burns et al., 1953; Whittaker and Evans, 1970) Metabolism of this compound is controlled by both polygenic and environmental factors, and in one family study the genetic contribution has been estimated to be about $66 \%$ (Whittaker and Evans, 1970).

A serious complication of therapy with phenylbutazone is the appearance of bone marrow hypoplasia. Theoretically this could be due to accumulation of the parent compound or oxyphenbutazone, the major metabolite which is known to be toxic to bone marrow, or to the production of an unusual but toxic metabolite. Other factors involving marnow restponsiveness, the mechanisms of which are ill understood, could also operate.

This study was undertaken first to determine whether or not there was a correlation in a population of healthy subjects between oxidation rates of acetanilide and of phenylbutazone. Acetanilide was chosen as a particularly suitable compound for study because $84 \%$ of it is oxidized to $N$ acetyl p-aminophenol (paracetamol), and the hepatic endoplasmic reticulum inserts one atom of oxygen in the para position of the benzene ring (Brodie and Axelrod, 1948 a). Phenylbutazone is also oxidized in the para position of its benzene ring but undergoes other less important biotransformations including oxidation on the aliphatic side chain (Burns et al., 1955).

The second aim was to test the hypothesis that the marrow hypoplasia associated with phenylbutazone therapy might be due to accumulation of the parent compounds occurring in subjects who were relatively inefficient paraoxidizers and using acetanilide as a test drug. It was not possible to evaluate directly the role of phenylbutazone or its metabolites in patients with marrow hypoplasia, since it would have been unethical to re-expose patients to this drug.

\section{Control Subjects}

The 30 volunteer control subjects were healthy and drug 
free. None suffered from allergy or had had gastrointestinal surgery. There were 18 men and 12 women. All were under 30 years of age except for two who were aged 42 years. Most were senior university students. This group was not matched for age with the two groups of patients though it is cleax from previous work that there is no significant correlation between age and rate of phenylbutazone metabolism in adult subjects (Whittaker and Evans, 1970; O'Malley et al., 1971). It should be noted, however, that O'Malley et al. (1971) found a lengthening of phenylbutazone half lives in 19 geriatric patients as compared with a younger group of 17 subjects. The mean difference between their groups, however, was not significant.

\section{Patients}

Two groups of patients with aplastic anaemia were studied. The diagnostic criteria for aplastic anaemia were pancytopenia and hypoplasia of the bone marrow at some time during the course of the illness. Pancytopenia was defined as anaemia $(\mathrm{Hb}<11.5 \mathrm{~g} / 100 \mathrm{ml}$ ), neutropenia (neutrophils $<2,500 / \mathrm{mm}^{3}$ ), and thrombocytopenia (platelets $<150,000 /$ $\mathrm{mm}^{3}$ ) (Dacie and Lewis, 1968). Marrow hypoplasia was established in all cases by examination of a marrow aspirate and a percutaneous needle biopsy.

Eight of the patients gave a history of exposure to phenylbutazone in various doses and for various periods of time before the onset of their illness and were presumed to have phenylbutazone-induced aplastic anaemia. None of these patients had seropositive rheumatoid arthritis. The other five patients gave no such history. Four were deemed to have a cryptogenetic aetiology and one gave a history of exposure to indomethocin for several years.

On the morning of the acetanilide test (see below) blood was taken at the same time as the blank blood specimen for haemoglobin estimation, white cell count, and measurement of urea, electrolytes, and liver function (serum aspartate aminotransferase (SGOT), serum alanine aminotransferase (SGPT), and alkaline phosphatase).

The haematological data at the time of diagnosis and before exposure to acetanilide, together with details of therapy are shown in table I. All the patients had normal blood urea and serum electrolyte levels. All but two had normal liver function on the above criteria both at the time of diagnosis and before the acetanilide test. These two patients, one from each group, had evidence of mild obstructive jaundice at the time of the acetanilide test only, thought to be due to concurrent oxymetholone therapy. The patient in case 7 had a serum bilirubin of $1.8 \mathrm{mg} / 100 \mathrm{ml}$ (conjugated $1.1 \mathrm{mg}$ and unconjugated $0.7 \mathrm{mg} / 100 \mathrm{ml}$ ), a serum alkaline phosphatase of $30 \mathrm{U} / 100 \mathrm{ml}$ (normal range 3-15 $\mathrm{U} / 100 \mathrm{ml}$ ), a SGOT of $60 \mathrm{IU} / 1$. (normal range 10-38 IU/1.), and a SGPT of $90 \mathrm{IU} /$ 1. (normal range 9-38 IU/1.). The other patient's (case 11) bilirubin level was $2.4 \mathrm{mg} / 100 \mathrm{ml}$ (conjugated $2.0 \mathrm{mg}$, unconjugated $0.7 \mathrm{mg} / 100 \mathrm{ml}$ ), alkaline phosphatase $30 \mathrm{U} / 100 \mathrm{ml}$, SGOT $104 \mathrm{IU} / 1$., and SGPT $119 \mathrm{IU} / 1$. Both were negative for Australia antigen and antibody.

One patient (case 8) was receiving prednisolone, which could have the effect of inducing the metabolism of acetanilide.

\section{Methods}

\section{ACETANILIDE TEST}

Before being admitted to the study all subjects gave their fully informed consent and were instructed not to take any drugs for two weeks previously except for specific steroid therapy being taken by the patient groups.

Participants were fasted overnight for 12 hours before the test. The following morning a blank blood specimen was taken and they swallowed acetanilide in a dose of $50 \mathrm{mg} / \mathrm{kg}$ metabolically active mass (M.A.M. = weight to the power of 0.7 ; Drabkin, 1959). A glass of water was taken with the

TABLE I-Haematological Data and Details of Therapy in Eight Patients with Phenylbutazone-associated Hypoplasia and Five Patients with Idiopathic Hypoplasia

\begin{tabular}{|c|c|c|c|c|c|c|c|c|c|c|c|}
\hline \multirow{3}{*}{$\begin{array}{l}\text { Case } \\
\text { No. }\end{array}$} & \multicolumn{6}{|c|}{ Data at Time of Diagnosis } & \multicolumn{5}{|c|}{ Data at Time of Acetanilide Test } \\
\hline & \multirow{2}{*}{$\begin{array}{l}\text { Age } \\
\text { and } \\
\text { Sex }\end{array}$} & \multicolumn{2}{|c|}{ Phenylbutazone Exposure } & \multirow{2}{*}{$\underset{(\mathrm{g} / 100 \mathrm{ml})}{\mathrm{Hb}}$} & \multirow{2}{*}{$\begin{array}{l}\text { Neutrophils } \\
\text { per } \mathrm{mm}^{3 *}\end{array}$} & \multirow{2}{*}{$\begin{array}{l}\text { Platelets } \\
\text { per } \mathrm{mm}^{\mathbf{3}}\end{array}$} & \multirow{2}{*}{$\begin{array}{c}\text { Acetanilide } \\
\text { Clearance } \\
(1 / \mathrm{hr})\end{array}$} & \multirow[b]{2}{*}{$\mathrm{Hb}$} & \multirow{2}{*}{$\begin{array}{l}\text { Neutrophils } \\
\text { per } \mathrm{mm}^{3 *}\end{array}$} & \multirow{2}{*}{$\begin{array}{l}\text { Platelets } \\
\text { per } \mathrm{mm}^{2 *}\end{array}$} & \multirow[b]{2}{*}{ Current Therapy } \\
\hline & & $\begin{array}{c}\text { Duration } \\
\text { (years) }\end{array}$ & $\begin{array}{c}\text { Dose } \\
\text { (mg/day) }\end{array}$ & & & & & & & & \\
\hline \multicolumn{12}{|c|}{ Patients with Phenylbutazone-associated Aplastic Anaemia } \\
\hline 1 & $62 \mathrm{~F}$. & 10 & 300 & $6 \cdot 4$ & $\begin{array}{c}360 \\
(19 \%)\end{array}$ & $<10,000$ & $19 \cdot 6$ & 6.4 & $\begin{array}{r}360 \\
(19 \%) \\
\end{array}$ & $<10,000$ & None \\
\hline 2 & $75 \mathrm{~F}$. & 3 & 300 & $4 \cdot 7$ & $\begin{array}{r}1458 \\
(54 \%) \\
\end{array}$ & $<10,000$ & 10.8 & $12 \cdot 2$ & $\begin{array}{l}1000 \\
(33 \%)\end{array}$ & 85,000 & $\begin{array}{c}\text { Oxymetholone } \\
300 \mathrm{mg}\end{array}$ \\
\hline 3 & $61 \mathrm{M}$ & 2 & 600 & 6.5 & $\begin{array}{r}1092 \\
(28 \%) \\
\end{array}$ & $<10,000$ & $14 \cdot 7$ & $13 \cdot 2$ & $\begin{array}{r}2320 \\
(40 \%) \\
\end{array}$ & 160,000 & $\begin{array}{c}\begin{array}{c}\text { Fluoxymethesterone } \\
10 \mathrm{mg}\end{array} \\
\end{array}$ \\
\hline 4 & $65 \mathrm{~F}$. & 4 & 300 & $9 \cdot 7$ & $\begin{array}{l}1900 \\
(38 \%) \\
\end{array}$ & 28,000 & 11.5 & $10 \cdot 0$ & $\begin{array}{r}780 \\
(19 \%) \\
\end{array}$ & 84,000 & None \\
\hline 5 & $79 \mathrm{~F}$. & 2 & 200 & $9 \cdot 2$ & $\begin{array}{r}430 \\
(12 \%) \\
\end{array}$ & $<10,000$ & $19 \cdot 3$ & $9 \cdot 2$ & $\begin{array}{r}430 \\
(12 \%) \\
\end{array}$ & $<10,000$ & None \\
\hline 6 & $64 \mathrm{~F}$. & 2 & 300 & $7 \cdot 4$ & $\begin{array}{r}640 \\
(20 \%) \\
\end{array}$ & 99,000 & $18 \cdot 4$ & $7 \cdot 4$ & $\begin{array}{r}640 \\
(20 \%) \\
\end{array}$ & 99,000 & $\begin{array}{l}\text { Oxymetholone } \\
150 \mathrm{mg}\end{array}$ \\
\hline 7 & $55 \mathrm{~F}$. & 9 & 300 & $9 \cdot 3$ & $\begin{array}{l}1444 \\
(38 \%) \\
\end{array}$ & 21,000 & 6.9 & $11 \cdot 7$ & $\begin{array}{r}960 \\
(20 \%) \\
\end{array}$ & 39,000 & $\begin{array}{c}\text { Oxymetholone } \\
150 \mathrm{mg}\end{array}$ \\
\hline 8 & $69 \mathrm{~F}$. & 0.5 & 300 & $5 \cdot 6$ & $\begin{array}{l}1050 \\
(16 \%)\end{array}$ & 24,000 & 11.5 & $13 \cdot 0$ & $\begin{array}{r}900 \\
(20 \%)\end{array}$ & $<10,000$ & $\begin{array}{l}\text { Prednisolone } \\
5 \mathrm{mg}\end{array}$ \\
\hline \multicolumn{12}{|c|}{ Patients with Idiopathic Aplastic Anaemia } \\
\hline 9 & $70 \mathrm{~F}$. & & & $9 \cdot 8$ & $\begin{array}{l}1500 \\
(30 \%) \\
\end{array}$ & 41,000 & $14 \cdot 6$ & $9 \cdot 2$ & $\begin{array}{l}1190 \\
(34 \%) \\
\end{array}$ & 15,000 & None \\
\hline 10 & $27 \mathrm{M}$. & & & $9 \cdot 3$ & $\begin{array}{r}1500 \\
(43 \%) \\
\end{array}$ & 50,000 & $27 \cdot 0$ & $9 \cdot 3$ & $\begin{array}{r}1530 \\
(43 \%) \\
\end{array}$ & 50,000 & $\begin{array}{c}\text { Oxymetholone } \\
150 \mathrm{mg} \\
\end{array}$ \\
\hline 11 & $48 \mathrm{M}$. & & & $10 \cdot 0$ & $\begin{array}{r}430 \\
(10 \%) \\
\end{array}$ & 74,000 & 19.5 & $11 \cdot 3$ & $\begin{array}{r}885 \\
(15 \%) \\
\end{array}$ & 112,000 & $\begin{array}{c}\text { Oxymetholone } \\
100 \mathrm{mg} \\
\end{array}$ \\
\hline 12 & $20 \mathrm{~F}$. & & & 8.5 & $\begin{array}{r}300 \\
(12 \%) \\
\end{array}$ & 20,000 & 16.9 & $15 \cdot 0$ & $\begin{array}{l}100 \\
(4 \%) \\
\end{array}$ & $<10,000$ & $\begin{array}{l}\text { Oxvmetholone } \\
50 \mathrm{mg} \\
\end{array}$ \\
\hline 13 & $36 \mathrm{M}$. & & & $7 \cdot 2$ & $\begin{array}{c}420 \\
(16 \%)\end{array}$ & $<10,000$ & 25.9 & $13 \cdot 5$ & $\begin{array}{l}1152 \\
(32 \%)\end{array}$ & 54,000 & None \\
\hline
\end{tabular}

*Percentages are of differential count. 
acetanilide, and fasting continued for two hours. Thereafter, a low-fat light diet was allowed. Blood was withdrawn at five, seven, and nine hours after acetanilide ingestion, heparinized, centrifuged, and the plasma stored at $-20^{\circ} \mathrm{C}$ to await acetanilide analysis. Each subject's blank value was deducted from his other three values.

Previous work on the decline of acetanilide in plasma with respect to time has shown that three points provide a reasonable approximation to results obtained by obtaining samples at six time points.

Assay of acetanilide in plasma was achieved using modification of the method described by Brodie and Axelrod $(1948$ b). A standard line containing duplicate standards at $0,2,4,6,8$, and $10 \mu \mathrm{g}$ of acetanilide per ml concentration was incorporated with each assay, and estimation of the unknown analysis was also carried out in duplicate.

\section{PHENYLBUTAZONE CORRELATION EXPERIMENT}

Davies and Thorgeirsson (1971) showed that single-dose half lives of antipyrine did not correlate with single dose half lives of phenylbutazone. When phenylbutazone was given for five days, however, and the half lives measured on stopping medication in eight subjects correlation was then shown between these "multiple-dose" half lives and single-dose half lives of antipyrine. Because of this consideration, phenylbutazone $100 \mathrm{mg}$ was given daily for eight days to 10 healthy volunteers who had previously had an acetanilide test, and the decline in plasma was measured. Blood samples were taken at 48, 72, and 96 hours after ingestion of the last tablet, centrifuged, heparinized, and stored at $-4^{\circ} \mathrm{C}$ to await analysis. All specimens were assayed within five days as it has been shown that phenylbutazone in plasma does not deteriorate within one week.

Phenvlbutazone was measured by the method of Burns et al. (1953). Further details of the methodology used are given by Whittaker and Evans (1970).

\section{CALCULATION OF CLEARANCE VALUES FOR}

\section{ACETANILIDE AND PHENYLBUTAZONE}

Half lives were computed from the linear regression of $\log _{10}$ phenylbutazone or acetanilide concentrations against time, the three available values being used in each case. The elimination constant $\left(K_{e l}\right)=0.693 /$ half life (hours). The apparent distribution volume $\left(V_{D}\right)$ was for acetanilide computed as Dose (mg)/Extrapolated plasma concentration at time 0 hours ( $\mu \mathrm{g}$ per $\mathrm{ml}$ ), expressed in litres.

A similar calculation was used to obtain the apparent distribution volume of phenylbutazone though time 0 hours was taken to be the time the last $100-\mathrm{mg}$ dose of phenylbutazone was taken. The total dose of phenylbutazone given to all subjects was $800 \mathrm{mg}$ though by the time that the half life was measured, some of this would have been metabolized and excreted. In the calculation of apparent distribution volume the dose was therefore expressed as 100 units.

It would have been possible to calculate the absolute value for phenylbutazone clearance from the steady state plasma concentration, but this was not achieved for all volunteers within eight days. Exposure of volunteers to this drug for a longer period was not considered to be ethical.

The clearance of both drugs was computed as $V_{D} \times \mathbf{K}_{\mathrm{el}}$. Clearance may be considered a satisfactory measurement of metabolism because it takes into account pool size as well as rate of change.

Student's $t$ test for unpaired data and correlation coefficient were used in the statistical analysis (Bailey, 1959).

\section{Results}

Results of the clearance of acetanilide in control subjects are summarized in table II and shown in fig. 1.

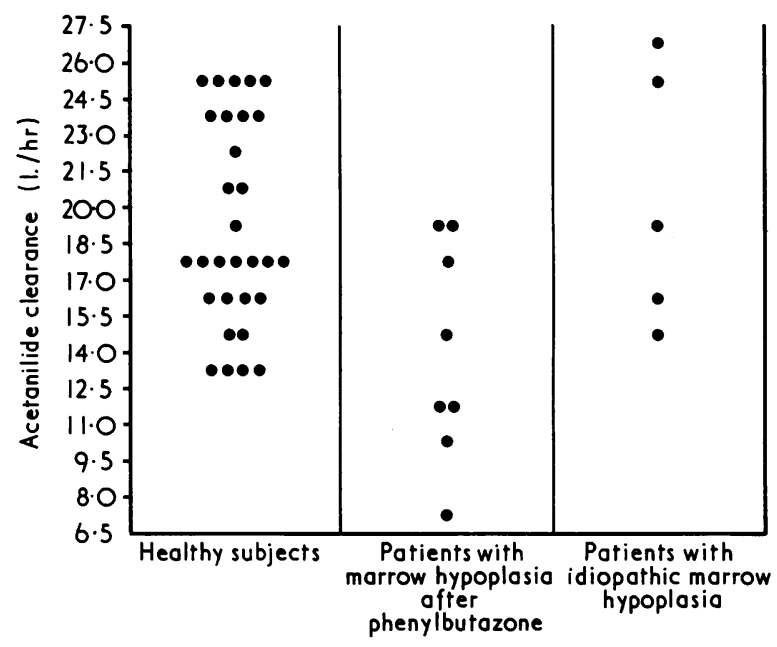

FIG. 1-Acetanilide clearance in three groups of subjects studied.

Clearance values for phenylbutazone in 10 of the 30 control subjects varied from $7.61 \mathrm{U}$ to $12.84 \mathrm{U} / \mathrm{hr}$. The mean ( \pm S.E.) was $10.7 \pm 0.67 \mathrm{U} / \mathrm{hr}$. Correlation was shown between the clearance of phenylbutazone and acetanilide in these 10 subjects $(r=+0.7067 ; P<0.05)$, fig. 2$)$.

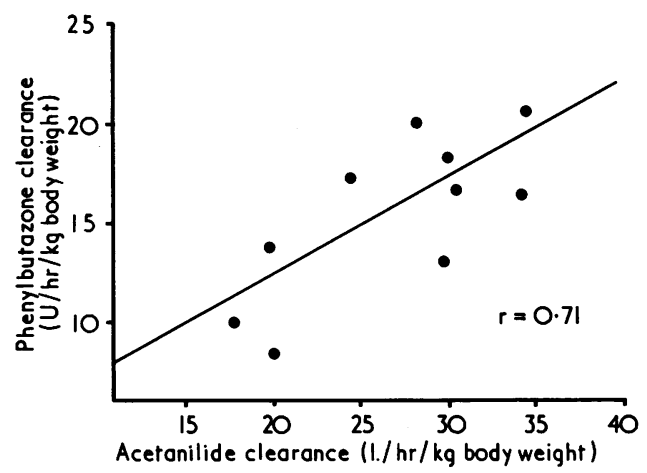

FIG. 2-Acetanilide clearance and phenylbutazone clearance in 10 volunteer subjects. Slope of regression line is significantly different from zero $(P<0.05)$.

TABLE II-Acetanilide Clearance and Half Life in Three Groups of Subjects. Statistical Comparisons are between Controls and Phenylbutazone-associated Hypoplasia Group and Controls and Idiopathic-Hypoplasia Group

\begin{tabular}{|c|c|c|c|c|c|c|c|}
\hline & \multirow{2}{*}{$\begin{array}{l}\text { No. of } \\
\text { Subjects }\end{array}$} & \multicolumn{2}{|c|}{$\begin{array}{c}\text { Acetanilide Clearance } \\
(1 . / \mathrm{hr})\end{array}$} & \multirow{2}{*}{$\begin{array}{l}t \text { and } \mathbf{P} \\
\text { Values }\end{array}$} & \multicolumn{2}{|c|}{$\begin{array}{c}\text { Acetanilide Half Life } \\
\text { (hrs) }\end{array}$} & \multirow{2}{*}{$\begin{array}{l}t \text { and } \mathbf{P} \\
\text { Values }\end{array}$} \\
\hline & & Range & $\begin{array}{l}\text { Mean } \pm \text { S.E. } \\
\text { of Mean }\end{array}$ & & Range & $\begin{array}{c}\text { Mean } \\
\text { of Mean }\end{array}$ & \\
\hline $\begin{array}{l}\text { Controls } \\
\text { Patients with phenylbutazone-associated hypoplasia }\end{array}$ & $\begin{array}{r}30 \\
5\end{array}$ & $\begin{array}{l}12 \cdot 4-25 \cdot 2 \\
14 \cdot 6-27 \cdot 0\end{array}$ & $\begin{array}{l}19 \cdot 2 \pm 0.76 \\
20 \cdot 8 \pm 2 \cdot 45\end{array}$ & $t=+0.7349$ & $\begin{array}{l}1 \cdot 6-6 \cdot 1 \\
2 \cdot 9-5 \cdot 2\end{array}$ & $\begin{array}{l}3.7 \pm 0.18 \\
4.2 \pm 0.37\end{array}$ & $t=\underset{P}{+}+1.1188$ \\
\hline Patients with idiopathic hypoplasia & 8 & $6 \cdot 9-19 \cdot 6$ & $14 \cdot 1 \pm 1 \cdot 65$ & $\begin{aligned} t & =-3.0471 \\
\mathrm{P}<0.01 & \end{aligned}$ & $4 \cdot 0-8 \cdot 3$ & $5.5 \pm 0.52$ & $\begin{aligned} t & =4.3211 \\
\mathrm{P} & <0.001\end{aligned}$ \\
\hline
\end{tabular}


The mean clearance value of acetanilide in patients with marrow hypoplasia unrelated to phenylbutazone ingestion was compared with the mean for the control group. The difference was not significant (table II; fig. 1).

The mean reduction in acetanilide clearance in patients with phenylbutazone-associated marrow hypoplasia was compared with the mean of the control group, and the difference was significant $(P<0.01$; table II; fig. 1). The results of measuring acetanilide half lives are summarized in table II.

Negative correlation was shown between the haemoglobin value at the time of the acetanilide test and the clearance of acetanilide in the eight patients with phenylbutazoneassociated marrow hypoplasia $(r=-0.7213 ; \mathrm{P}<0.05)$. The mean haemoglobin level of the phenylbutazoneassociated group, however, was not significantly different from the mean haemoglobin in the non-phenylbutazoneassociated group $(t=0.8699 ; P>0.05)$. In all 13 patients with marrow damage there was no relation between the haemoglobin and acetanilide clearance $(r=-0.2067 ; \mathrm{P}>$ 0.05).

There was no relation between the half lives of acetanilide and haemoglobin levels in the 13 subjects taken together $(r=-0.2173 ; \mathrm{P}>0.05)$ nor between acetanilide half lives and haemoglobin levels in the eight subjects with phenylbutazone-associated marrow hypoplasia $(r=0.0638$; $P>0.05)$.

\section{Discussion}

Bone marrow damage is a serious complication of phenylbutazone therapy. Phenylbutazone is the commonest cause of drug-induced aplasia in the U.K. and second only to chloramphenicol aplasia in the U.S.A. A total of 173 cases of aplastic anaemia considered to be associated with phenylbutazone were reported to the adverse reactions subcommittee of the Committee on Safety of Medicines in period January 1964 to December 1973. Of these 128 died. Depression of other individual formed elements of the marrow were also reported associated with phenylbutazone and with similarly formidable death rates. Williams et al. (1973) recently reviewed 101 cases of aplastic anaemia seen in their unit in Salt Lake City, Utah, since 1944. Thirty-five were due to chloramphenicol, eight to sulphonamides, and two to phenylbutazone, while at Manchester Royal Infirmary over a similar period 172 cases were seen, of which 12 were due to phenylbutazone, eight to sulphonamides, and seven to chloramphenicol.

This work produces evidence to suggest that phenylbutazone accumulation due to delayed oxidation is a mechanism which may predispose to marrow damage, but there are difficulties in interpreting observations made on patients with varying degrees of illness. For instance, the patient in case 7 could be considered an atypical subject, having a long acetanilide half life and slow clearance. She was also mildly jaundiced (though a comparable subject in the nonphenylbutazone-associated hypoplastic group was also icteric). Omitting case 7 from the phenvlbutazone-associated hvpoplasia group, the mean haemoglobin levels of the two patient groups were still not significantly different $(t=0.9394$ $P>0.05$ ). Again omitting case 7 , the mean clearance of acetanilide in the phenvlbutazone-associated group was still significantly reduced when compared with the 30 control subiects $(t=-2.3921 ; P<0.05)$.

The effect of anaemia has been stated above, there being a negative correlation between haemoglobin and acetanilide clearance in the eight subjects with phenylbutazoneassociated hvpoplastic anaemia-that is, anaemia had the effect of raising acetanilide clearance (presumably due mainly to increasing apparent distribution volume). The effect of increased blood flow (to all body organs including liver and kidney) in anaemia may also be relevant. This would mili- tate against the result actually found so that there might be an even lower rate of clearance in subjects with phenylbutazone-associated hypoplasia than in controls. Similarly, when comparing the five non-phenylbutazone-induced subjects with controls despite some anaemic subjects in the former group the mean acetanilide clearances were very similar.

Das et al. (1973) investigating adverse reactions during salicylazosulphapyridine therapy concluded that most of the toxic symptoms ascribed to this compound could be related to high serum concentrations of total sulphapyridine. Most subjects suffering side effects were slow acetylator phenotypes. One of their patients suffered from agranulocytosis and another from a reversible leucopenia, which did not reappear when salicylazosulphapyridine was reintroduced in a smaller dose. Both these patients had high serum levels of total sulphapyridine at the time of the discovery of the marrow injury.

Yunis (1973) has recently reviewed the pathogenesis of bone marrow damage due to chloramphenicol. There is both clinical and experimental evidence that there are two distinct and unrelated types. Firstly, and much more commonly, there is a dose-related reversible inhibition of both mitochondrial protein synthesis and haem synthetase in red cell precursors. The depletion of haem synthetase is accompanied by a rise in free red cell protoporphyrins. In addition vacuolation of the marrow cells is observed by the light microscope and mitochondrial changes by the electron microscope. These effects are seen whenever chloramphenicol is given in sufficiently high doses, and all revert to normal within weeks of the drug being stopped.

Secondly, and much more rarely, there is the chloramphenicol-induced marrow aplasia which is unrelated to doce or duration of administration. This strongly suggests an individual predisposition. In-vitro marrow studies on these patients indicate that the effect is genetic and probably involves a single gene.

There may be two such mechanisms in the pathogenesis of phenylbutazone-induced marrow hvpoplasia. These results suggest, however, that drug accumulation is the major factor and it has been shown in the Manchester depantment (unpublished observation) that red cell protoponphyrins are raised in the same way as in chloramphenicol-induced aplasia due to excessive drug administration. The difference lies in the fact that in phenylbutazone-induced aplasia the red cell protoporphyrins remain raised even afiter partial or apparent complete remission. In one patient the aplasia was followed by frank sideroblastic anaemia (Geary et al., 1974). These facts suggest that the marrow damage is irreversible.

The second tvpe of marrow damage occurring in rare phenotypes described for chloramphenicol could also have a parallel for phenvlbutazone and be unrelated to drug accumulation; phenvlbutazone may be biotransformed to hitherto unknown metabolites. The evidence from this work, however, is that accumulation of phenvlbutazone mav be an important factor. A similar pattern of adverse reactions has been reported to the Committee on Safety of Medicines for both phenvlbutazone and oxvphenbutazone and would not be explained on the basis of the foregoing. It follows from this that the monitoring of phenvlbutazone plasma levels in patients receiving continued therapy may serve to identify subjects with high drug concentrations in the plasma, thereby offering a possibility of reducing the incidence of fatal side effects due to marrow damage.

We thank the Wellcome Trust for the Fellowship held by J.L.C. during the preparation of this work; the Adverse Reactions Subcommittee of the Committee on Safety of Medicines for information about adverse reactions to phenylbutazone and oxyphenbutazone; Miss M. F. Bullen, S.R.N., of the department of medicine, Univer$\mathrm{si}^{+} \mathrm{v}$ of Liverpool, for help with the collection of plasma specimens; Miss B. Young, S.R.N., and staff of the programmed investigation unit at M.R.I.; and Miss H. Wright for secretarial help. 


\section{References}

Bailey, N. T. J. (1959). Statistical Methods in Biology. London, English Universities Press.

Brodie, B., and Axelrod, J. (1948 a). Fournal of Pharmacology and Experimental Therapeutics, 94, 29

Brodie, B., and Axelrod, J. (1948 b). Fournal of Pharmacology and Experimental Therapeutics, 94,22

Burns, J. J., et al. (1953). Fournal of Pharmacology and Experimental Therapeutics, 109, 346.

Burns, J. J., et al. (1955). Fournal of Pharmacology and Experimental Therapeutics, 113, 481 .
Dacie, J. V., and Lewis, S. M. (1968). Practical Haematology, 4th edn., p. 12. London, Churchill.

Davies, D. S., and Thorgeirrson, S. S. (1971). Annals of the New York Academy of Sciences, 179, 411

Drabkin, D. L. (1959). Perspectives in Biology and Medicine, 2, 473.

Geary, G. C., et al. (1974). British fournal of Haematology. In press.

O'Malley, K., et al. (1971). British Medical fournal, 3, 607.

Whittaker, J. A., and Evans, D. A. P. (1970). British Medical fournal, 4, 323.

Williams, D. M., Lynch, R. E., and Cartwright, G. E. (1973). Seminars in Hematology, 10, 195.

Yunis, A. A. (1973). Seminars in Hematology, 10, 225.

\title{
A Further Application of the Nitroblue Tetrazolium Test
}

\author{
R. M. ROWAN, A. M. GORDON, A. K. R. CHAUDHURI， F. MORAN
}

British Medical fournal, 1974, 3, 317-319

\section{Summary}

The nitroblue tetrazolium (N.B.T.) test was performed on patients in whom a differential diagnosis of pulmonary thromboembolism or lobar pneumonia existed. The mean N.B.T. score in healthy subjects was $6.4 \%$ (range $1 \%$ $15 \%$ ). Patients with uncomplicated pulmonary thromboembolism showed a mean N.B.T. value of $7.5 \%$ (range 3\%$12 \%)$. In patients with lobar pneumonia the mean N.B.T. score was $42 \cdot 4 \%$ (range $21 \%-85 \%$ ). These results suggest that the N.B.T. test is of value in the differential diagnosis of pulmonary thromboembolism and lobar pneumonia.

\section{Introduction}

It is widely known that patients with pulmonary thromboembolic disease often present with chest pain, pyrexia, leucocytosis, and radiographical opacity in the lung fields, with or without haemoptysis, thus simulating lobar pneumonia. The differentiation of infective from noninfective pulmonary lesions can therefore be extremely difficult in the absence of specialized techniques. A rapid and easily performed test facilitating this distinction would clearly be of considerable diagnostic value.

The nitroblue tetrazolium (N.B.T.) test is now established as a useful screening procedure for the detection of systemic bacterial infection and for its differentiation from pyrexial syndromes of non-bacterial origin (Park et al., 1968; Lancet, 1971; Gordon and Rowan, 1973 a; Gordon et al., 1973).

We performed N.B.T. tests on blood samples from patients in whom a differential diagnosis of lobar pneumonia or pulmonary thromboembolism existed. We report here our experience of this test as a means of differentiating these conditions.

\section{Subjects and Methods}

Three groups of people were studied: 71 normal controls of

Royal Infirmary, Glasgow G4 OSF

R. M. ROWAN, M.B., M.R.C.P., Consultant Haematologist

A. M. GORDON, M.B., M.R.C.PATH., Consultant Bacteriologist, University Department of Bacteriology

F. MORAN, M.B., F.R.C.P., Consultant Physician Centre for Respiratory Investigation

Department of Infectious Diseases, Belvidere Hospital, Glasgow G31 4PG

A. K. R. CHAUDHURI, M.B., M.R.C.P., Medical Assistant age range 17-79 years ( 35 men, 36 women), 14 patients with pulmonary thromboembolism, and 10 patients with lobar pneumonia. The principal presenting features in all patients were pyrexia, haemoptysis, and pleuritic pain. Clinical and radiographical evidence of pulmonary consolidation was present in all patients. Total and differential white cell counts were performed. Certain patients were subjected to pulmonary angiography. Among the criteria for selection for angiography were sudden onset of chest pain without previous respiratory symptomatology, history of deep vein thrombosis, recent surgery, recent pregnancy, or other predisposing factors to venous thrombosis; one patient was taking an oral contraceptive. The angiographic diagnosis of pulmonary thromboembolism was made on some or all of the following criteria: (a) filling defects in pulmonary arteries, (b) sharply cut-off vessels, $(c)$ avascular opacities, $(d)$ asymmetrical or asynchronous blood flow through arteries and veins (Simon and Sasahara, 1965). Additional evidence was obtained from detection of increased pressures in the pulmonary arterial circulation, usually in the absence of raised "wedged" pressure (indirect left atrial pressure). In some patients remeasurement of pressures after an interval of days showed a fall or a return to normal values.

The collection and processing of blood for the N.B.T. test was carried out by the method previously described by Gordon et al. (1973).

Whenever possible samples were processed immediately. When delay was unavoidable specimens were stored at $4^{\circ} \mathrm{C}$ (for a maximum of 12 hours) to prevent spontaneous enhancement of N.B.T. dye reduction (Winchester et al., 1973). The criteria of neutrophil positivity were intracytoplasmic block deposits of formazan equalling or exceeding the size of individual neutrophil lobes (Segal et al., 1973; Gordon and Rowan, 1973 b). Stippled cells were disregarded. Only intact neutrophils with clearly defined cell membranes were included in the count.

\section{Results}

The diagnosis of pulmonary thromboembolism was substantiated by angiography in 11 patients. In the three remaining patients the diagnosis was made on clinical and radiographical grounds. A satisfactory response to a continuous infusion of heparin occurred, however, in each patient in the absence of antibiotic therapy. Two patients with lobar pneumonia were subjected to angiography. No angiographic abnormality was found in either case. All patients with lobar pneumonia responded completely to antibiotic therapy.

One patient (case 14) with angiographically proven pulmonary embolism was in addition shown to be suffering from Mycoplasma pneumoniae infection (complement fixation titres obtained on paired sera: 1/256, 1/64). 